\title{
Optimization of Variables for Aqueous Extraction of Gum from Grewia mollis Powder
}

\author{
Emmanuel Panyoo Akdowa, ${ }^{1,2}$ Thaddee Boudjeko, ${ }^{3}$ Alice Louise Woguia, ${ }^{3}$ \\ Nicolas Njintang-Yanou, ${ }^{4}$ Claire Gaiani, ${ }^{2}$ Joel Scher, ${ }^{2}$ and Carl Moses F. Mbofung ${ }^{1}$ \\ ${ }^{1}$ ENSAI, University of Ngaoundere, P.O. Box 454, Ngaoundere, Cameroon \\ ${ }^{2}$ Laboratoire d'Ingénierie des Biomolécules, Université de Lorraine, 2 avenue de la Forêt de Haye, B.P. 172, \\ 54500 Vandoeuvre-lès-Nancy, France \\ ${ }^{3}$ Department of Biochemistry, Faculty of Science, University of Yaounde I, P.O. Box 812, Yaounde, Cameroon \\ ${ }^{4}$ Faculty of Science, University of Ngaoundere, P.O. Box 454, Ngaoundere, Cameroon \\ Correspondence should be addressed to Nicolas Njintang-Yanou; njintang@yahoo.fr
}

Received 29 August 2013; Accepted 27 November 2013; Published 23 March 2014

Academic Editor: Yves Grohens

Copyright (C) 2014 Emmanuel Panyoo Akdowa et al. This is an open access article distributed under the Creative Commons Attribution License, which permits unrestricted use, distribution, and reproduction in any medium, provided the original work is properly cited.

\begin{abstract}
Grewia gum is a polysaccharide derived from the inner stem bark of the edible plant Grewia mollis. Juss (family Tiliaceae). It is a savanna shrub that grows wildly but is usually cultivated in Nigeria and Northern part of Cameroon. The main goal of the present study was to investigate the effect of aqueous extraction conditions on the extraction yield and physicochemical properties of the Grewia mollis. The studied aqueous extraction variables were water/powder (W/P) ratio $(10: 1-80: 1 \mathrm{w} / \mathrm{p})$, temperature (25.0$\left.85.0^{\circ} \mathrm{C}\right)$, time $(1-3 \mathrm{~h})$, and $\mathrm{pH}(4.0-10.0)$. The results indicated that the aqueous extraction variables exhibited the least significant $(P<0.05)$ effect on the yield and the viscosity of the gum. The result shows that the ratio of extraction is the main factor affecting the extraction of gum. The optimized extraction condition for higher viscosity was at the powder/water ratio of 1:55.4, $\mathrm{pH}$ of 7 , time of $1 \mathrm{~h}$, and temperature of $50^{\circ} \mathrm{C}$. However, the optimized extraction condition for higher yield was at the powder/water ratio of $1: 80, \mathrm{pH}$ of 4 , time of $3 \mathrm{~h}$, and temperature of $73^{\circ} \mathrm{C}$.
\end{abstract}

\section{Introduction}

Grewia mollis is a shrub or tree widely distributed in SudanoSahelian region and found in Cameroon and Nigeria. The dried and pulverized inner stem bark is used as a thickening agent in some local dishes [1]. In the Adamawa region of Cameroon in particular, the powder is used as binding agent in the preparation of maize fried cake. This functionality is also exploited in Nigeria where it is used in cooking soup, or dried and pulverized to mix with bean meal to make cakes locally called in Hausa "Kosai" [2]. The functional properties of Grewia powder have been associated with the presence of mucilage, a polysaccharide nature [3]. In addition, the mucilage of the bark is used traditionally by the Yoruba people of Nigeria at child birth [2]. Phytochemical studies on the leaves and stem bark of Grewia mollis indicate the presence of tannins, saponins, flavonoids, glycosides, phenols, and steroids and the absence of alkaloids [4].

In overall and in the limit of our knowledge, the literature on Grewia reported mainly the evaluation of the performance of fine powder of stem bark as binders substitute in tablet formulation [2] and the toxic effect of the powder on experimental rats [5]. Results revealed that Grewia gum compares favorably with the standard binder Polyvinylpyrrolidone (PVP) and could be a useful substitute binder in paracetamol tablet formulations [2]. In addition consumption of Grewia powder by rat models showed no significant effect on serum alkaline phosphatase activity, urea, creatinine, triglycerides, cholesterol, glucose concentrations, and body and organ weights. However significant $(P<0.05)$ increase in serum transaminases activities was observed, accompanied by decrease in food intake in rats fed $10 \%$ stem bark suggest- 
ing some liver injury upon consumption of high level of the powder. While studies on Grewia have been interested on the powder of the stem back, a fundamental question concerning the functionality of the isolate Grewia stem bark gum is still to be answered. In doing this, the extraction conditions of the gum need to be determined and the question underlying the present study is what are the effect of extraction conditions on the viscosity and the yield of Grewia gum since these parameters constitute the determinant factors conditioning their trade, technological and nutritional qualities? In fact the most important properties of hydrocolloids are their viscosity (including thickening and gelling) and water binding. Other significant functions include emulsion stabilisation, prevention of ice recrystallisation, and improvement of organoleptic properties [6]. And the food hydrocolloid industry represents a market of over US $\$ 3.0$ billion [7]. To our knowledge, very few if no studies have been conducted on the extraction and evaluation of the functional properties of Grewia gum.

Generally, hot-water treatment has been used for extraction of hydrocolloid gums and is time, temperature, $\mathrm{pH}$, and water to mass ratio dependent [8]. Several studies are reported on various gums and the extracting conditions which give the optimal viscosity and yield varied from one plant species to another $[9,10]$. It is important therefore to optimize the extraction process in order to obtain the highest yield and quality polysaccharides. In the extraction processes, there are multiple independent variables affecting the responding factors. In addition, the possibility of interactions between the independent variables should be considered in order to determine the optimal experimental conditions [9]. Response surface methodology (RSM) has been reported to be an effective tool and successfully used for optimization of a process when the independent variables have a combined effect on the desired response [10, 11]. However, no study has been conducted on the extraction process of Grewia mollis gum.

Therefore, the objectives of the present work are (1) to study the effect of extraction time, temperature, $\mathrm{pH}$, and water to powder ratio on the extraction yield and viscosity of gum from stem bark Grewia mollis (2) to find out the optimum conditions for extraction of the gum from Grewia mollis powder using response surface methodology.

\section{Material and Methods}

2.1. Sampling and Proximate Analysis. Grewia mollis stem barks were procured from the local medical plant market, in Maroua, Cameroon. The stem barks were manually cleaned to remove all extraneous matter such as dust, dirt, stones, and chaff. The cleaned barks were then packed in plastic bags, sealed, and preserved in a dry and cool place. The moisture, ash, fat, and protein contents of the bark were measured [12]. The available sugar content was determined as previously described [13].

2.2. Gum Extraction Procedure. Aqueous Grewia mollis stem bark gum was extracted from the bark powder using distilled water (water to powder ratio $10: 1$ to $80: 1$ ) at $\mathrm{pH} 4$ to 10 following the experimental design shown in Table 1. The
$\mathrm{pH}$ was adjusted with $0.1 \mathrm{M} \mathrm{HCl}$ or $\mathrm{NaOH}$. Water was preheated to a designated temperature before the powder was added. The powder water slurry was mixed throughout the extraction period ( $1 \mathrm{~h}$ to $3 \mathrm{~h}$ ). Separation of the gum from the swollen powder was achieved by passing the powder through an extractor with a rotating plate that scraped the gum layer on the powder surface. The collected gum was filtered and dried in an oven $\left(45^{\circ} \mathrm{C}\right.$ overnight). The dry gum was packed and stored at cool and dry conditions [14].

2.3. Determination of the Response Variable. Two response variables were used in this work, the gum yield and the viscosity. The yield was calculated as the ratio of dry weights of the powder obtained after lyophilization to the initial powder weight and expressed as $\mathrm{g} / \mathrm{kg}$. The apparent viscosity of the hydrated samples $(2.5 \% \mathrm{w} / \mathrm{w})$ was measured at constant conditions (temperature $25^{\circ} \mathrm{C}, \mathrm{pH} 7$, and shear rate $1000 \mathrm{~s}^{-1}$ ) using a rotational viscometer (Kinexus, Malvern instruments) fitted with plate geometry.

2.4. Monosaccharide Profile. The monosaccharide profile of the gum powder extracted at optimum conditions was determined as reported earlier [15]. In the procedure, $2 \mathrm{mg}$ of lyophilized gum was hydrolysed in $2 \mathrm{~mL}$ of $2.5 \mathrm{M}$ trifluoroacetic acid at $100^{\circ} \mathrm{C}$ for $2 \mathrm{~h}$ in a sealed tube under nitrogen. After hydrolysis the acid was removed on a rotary evaporator, and the hydrolysate was reduced with sodium borohydride and acetylated [16]. The resulting alditol acetate derivatives were separated on a $1.85 \mathrm{~m} \times 4 \mathrm{~mm}$ column of 3\% SP2 on 100/120 Supelcoport, in a Hewlett-Packard model 5710A gas chromatograph. The chromatography was conducted isothermally at $215^{\circ} \mathrm{C}$ with an $\mathrm{N}_{2}$-carrier-gas flow rate of $60 \mathrm{~mL} / \mathrm{min}$.

2.5. Experimental Design and Statistical Analysis. Response surface methodology (RSM) was used to fit the independent variables to the response variables apparent viscosity $(\mathrm{Pa} \cdot \mathrm{s})$ and gum yield $(\mathrm{g} / \mathrm{kg})$. A face-centered central composite design was used with 4 factors, namely, extraction temperatures $\left(25-85^{\circ} \mathrm{C}\right), \mathrm{pH}(4-10)$, water to seed ratio $(10: 1-80: 1)$, and extraction time $(1 \mathrm{~h}-3 \mathrm{~h})$. The design variables in this study with actual and coded levels are shown in Table 1 . The statistical package Minitab 16 was used for statistical analysis. The experimental design was composed of 30 experiments including $2^{4}$ full factorial design points, 8-star points, and 6centre points. The significant terms in different models were found by analysis of variance (ANOVA) for each response. Significance was judged by determining the probability level that the $F$ statistic calculated from the data is less than 5\%. Numerical optimization technique of the sigma plot software was used for simultaneous optimization of the multiple responses. The desired goals for each variable and response were chosen. All the independent variables were kept within range while the responses were maximized.

\section{Results and Discussion}

3.1. Chemical Composition of Grewia mollis Bark Powder. The chemical composition of Grewia mollis bark powder is 
TABLE 1: Matrices of the face-centered central design for the independent variables (experimental and coded levels).

\begin{tabular}{|c|c|c|c|c|c|c|}
\hline \multirow{2}{*}{ Number run } & \multicolumn{4}{|c|}{ Factors } & \multicolumn{2}{|c|}{ Responses variables } \\
\hline & Time $(\mathrm{H})$ & $\mathrm{pH}$ & Temperature $\left({ }^{\circ} \mathrm{C}\right)$ & Ratio & Viscosity $(\mathrm{Pa} \cdot \mathrm{s})$ & Gum yield \\
\hline 1 & $(+1) 3$ & (-1) 4 & $(-1) 25$ & $(+1) 80$ & 0.4339 & 0.6226 \\
\hline 2 & $(-1) 1$ & $(-1) 4$ & $(+1) 85$ & $(+1) 80$ & 0.2551 & 0.8174 \\
\hline 3 & $(-1) 1$ & $(+1) 10$ & $(+1) 85$ & $(-1) 10$ & 0 & 0 \\
\hline 4 & $(-1) 1$ & $(-1) 4$ & $(-1) 25$ & $(-1) 10$ & 0 & 0 \\
\hline 5 & (0) 2 & $(-1) 4$ & (0) 55 & (0) 45 & 0.3119 & 0.3248 \\
\hline 6 & (0) 2 & $(+1) 10$ & (0) 55 & (0) 45 & 0.3481 & 0.2438 \\
\hline 7 & (0) 2 & $(0) 7$ & (0) 55 & (0) 45 & 0.8363 & 0.231 \\
\hline 8 & (0) 2 & (0) 7 & $(+1) 85$ & (0) 45 & 0.3085 & 0.227 \\
\hline 9 & (0) 2 & (0) 7 & (0) 55 & (0) 45 & 1.023 & 0.945 \\
\hline 10 & (0) 2 & (0) 7 & (0) 55 & (0) 45 & 1.1 & 0.409 \\
\hline 11 & (+1) 3 & $(+1) 10$ & $(-1) 25$ & $(+1) 80$ & 0.543 & 0.5436 \\
\hline 12 & (+1) 3 & $(+1) 10$ & $(-1) 25$ & $(-1) 10$ & 0 & 0 \\
\hline 13 & (0) 2 & (0) 7 & (0) 55 & (0) 45 & 0.834 & 0.285 \\
\hline 14 & (+1) 3 & $(+1) 10$ & $(+1) 85$ & $(-1) 10$ & 0 & 0 \\
\hline 15 & $(-1) 1$ & $(+1) 10$ & $(+1) 85$ & $(+1) 80$ & 0.3931 & 0.2006 \\
\hline 16 & $(+1) 3$ & $(+1) 10$ & $(+1) 85$ & $(+1) 80$ & 0.3107 & 0.3014 \\
\hline 17 & (+1) 3 & $(-1) 4$ & $(+1) 85$ & $(-1) 10$ & 0 & 0 \\
\hline 18 & (0) 2 & (0) 7 & (0) 55 & $(-1) 10$ & 0 & 0 \\
\hline 19 & $(-1) 1$ & $(-1) 10$ & $(-1) 25$ & $(-1) 10$ & 0 & 0 \\
\hline 20 & (+1) 3 & (0) 7 & (0) 55 & (0) 45 & 0.6979 & 0.177 \\
\hline 21 & $(-1) 1$ & (0) 7 & (-1) 25 & (0) 45 & 1.214 & 0.285 \\
\hline 22 & $(-1) 1$ & $(+1) 10$ & $(-1) 25$ & $(+1) 80$ & 0.8223 & 0.1608 \\
\hline 23 & (0) 2 & (0) 7 & (0) 55 & $(+1) 80$ & 0.4639 & 0.092 \\
\hline 24 & $(-1) 1$ & $(-1) 10$ & $(-1) 25$ & $(+1) 80$ & 0.4084 & 0.3346 \\
\hline 25 & (+1) 3 & $(-1) 4$ & $(-1) 25$ & $(-1) 10$ & 0 & 0 \\
\hline 26 & (0) 2 & (0) 7 & (0) 55 & (0) 45 & 0.5126 & 0.187 \\
\hline 27 & $(-1) 1$ & $(-1) 10$ & $(+1) 85$ & $(-1) 10$ & 0 & 0 \\
\hline 28 & (0) 2 & (0) 7 & $(-1) 25$ & (0) 45 & 0.4045 & 0.272 \\
\hline 29 & $(+1) 3$ & $(+1) 10$ & $(+1) 85$ & $(+1) 80$ & 0.2885 & 0.5906 \\
\hline 30 & (0) 2 & (0) 7 & (0) 55 & (0) 45 & 1.333 & 0.343 \\
\hline
\end{tabular}

presented in Table 2. The bark powder was relatively low in moisture and mainly composed of available sugars. Ash was also highly represented but the protein level was average. This was the first time, at the best of our knowledge, the proximate composition of the bark of Grewia mollis was reported. The composition generally reflected the composition of bark of other plants reported in the literature. In fact our previous report on Scorodophleus zenkeri and Hua gabonii barks revealed range compositions of $9.7-96 \mathrm{~g} / 100 \mathrm{mg}$ DM for ash, 10.2-14.2 g/100 g DM for proteins, $2.5-3 \mathrm{~g} / 100 \mathrm{~g}$ for lipids, and 3.2-20.5 g/100 g DM for available carbohydrate. Basically the structure of plants bark is mainly composed of fibers and may contain resin, calcium oxalate cristal, tannins, and secretory elements [17]. The high level of available sugars in our bark sample reflected the high level of gum which has been shown to be essentially carbohydrate nature [3] such as Arabic gum, Tragacanth gum, and Karaya gum.

3.2. Monosaccharide Composition of the Gum. The monosaccharide composition of Grewia gum is presented in Figure 1.
TABLE 2: Chemical composition of Grewia mollis shrub powder.

\begin{tabular}{lc}
\hline Parameters & Levels \\
\hline Moisture content $(\mathrm{g} / 100 \mathrm{~g})$ & $12.3 \pm 0.11$ \\
Proteins $(\mathrm{g} / 100 \mathrm{gDM})$ & $7.8 \pm 0.55$ \\
Ash $(\mathrm{g} / 100 \mathrm{gDM})$ & $12.6 \pm 0.05$ \\
Available sugars $(\mathrm{g} / 100 \mathrm{gDM})$ & $43.9 \pm 2.13$ \\
Lipids $(\mathrm{g} / 100 \mathrm{gDM})$ & $2.5 \pm 0.42$ \\
\hline
\end{tabular}

The mean relative concentration of these sugars in the polysaccharide is glucose $(80 \%)$, rhamnose $(19 \%)$, xylose (5\%), galactose $(1 \%)$, and arabinose $(2 \%)$. Our results are quite similar to those previously reported by Nep and Conway [3] composed of glucose (67.1\%), rhamnose (6.2\%), arabinose $(12.7 \%)$, xylose $(2.7 \%)$, and galactose $(9.61 \%)$. Our sample also presented considerable levels of galacturonic acid and glucuronic acid which have been revealed earlier in Grewia gum by Fourier transformed infrared spectroscopy [18]. The difference in composition of our gum with reported data may reflect the difference in the molecular weight of the 


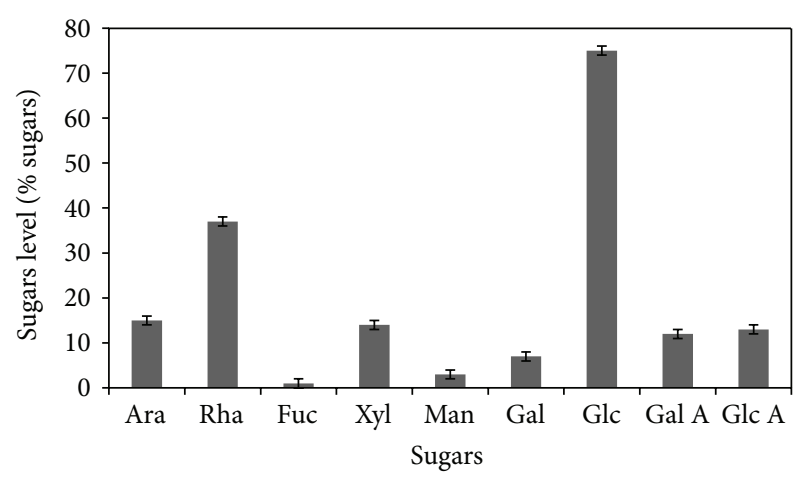

FIGURE 1: Monosaccharide profile by gas chromatography analysis.

polysaccharides which has been reported to vary depending on a number of factors such as the pathway and environment of synthesis, and the prevailing conditions under which the polysaccharide was extracted [19]. We used hot aqueous extraction in this work while Nep and Conway [3] used room temperature extraction followed by drying using varying methods.

3.3. Data Analysis of the Extraction Process. The analysis of the data generated from responses surface methodology generally assumes a second order polynomial equation showing relationship between the response variable(s) and the factors. In this equation the linear $\left(x_{i}\right)$, the interactions $\left(x_{i} x_{j}\right)$, and quadratic $\left(x_{i}^{2}\right)$ effects of each factor on the response variable(s) are determined. Tables 3 and 4 give the values of the effects and the associated analysis of variances for viscosity and extraction yield, respectively. $P$ value less than 0.05 indicated significant coefficients. In this respect the linear effect of the ratio was the most significant either for the viscosity $(P<0.0062)$ or the yield $(P<0.0009)$. In addition the quadratic effects of ratio $(0.0212)$ and time $(0.0542)$ were significant for the viscosity. On a comparative basis, the importance of the independent variables on viscosity could be ranked in the following order water to powder ratio > extraction time $>$ extraction temperature $>$ extraction $\mathrm{pH}$. Koocheki et al. [11] working on extraction of Qodume Shirazi gum also found similar significant effect of water : seeds ratio and temperature on the yield and viscosity of the gum while $\mathrm{pH}$ has a lesser effect. Reversely Razavi et al. [20] observed a nonsignificant effect of water: seed ratio on the viscosity and a significant effect on yield. Amid and Mirhosseini [21] observed a significant effect of ratio, temperature, and $\mathrm{pH}$ on the extraction yield of gum from durian (Durio zibethinus) seeds. The difference in the effect of factors on the responses variables may reflect the chemical structure of the gum. Grewia gum has been shown to be composed of mainly neutral sugars, and some uronic acid [18] is revealed here as galacturonic acid and glucuronic acid.

3.4. Effect of Factors on the Yield and Viscosity. The effect of ratio water/powder, time, temperature, and $\mathrm{pH}$ on the responses factors is presented in Figures 2(a), 2(b), 2(c), and $2(\mathrm{~d})$, respectively. The quadratic equations used were delivered when other factors were kept at the centre of the design (coded value equal to zero). Figure 2(a) showed that an increase in water to powder ratio from $10: 1$ to $51: 1$ induced an increase in yield to an optimum of $0.78 \%$ followed by a decrease in a yield value of $0.37 \%$ when the ratio varied from $51: 1$ to $80: 1$. Similar quadratic behavior of the effect of water to powder ratio was observed on the viscosity which showed an optimum at ratio $69: 1$, equivalent to a maximum viscosity of $0.39 \mathrm{~Pa} \cdot \mathrm{s}$. The effects of extraction time, extraction temperature, and $\mathrm{pH}$ represented, respectively, in Figures 2(b), 2(c), and 2(d) showed no significant variation on the viscosity and gum yield as confirmed by the ANOVA in Tables 3 and 4 .

The effect of extraction time and temperature, water to mass ratio, and $\mathrm{pH}$ on the gum yield and viscosity has been reported in various cases. Koocheki et al. [11] reported that the yield increased exponentially with temperature and time of extraction. At higher temperature around $75^{\circ} \mathrm{C}$ and higher time around $3 \mathrm{~h}$, yield reached nearly equilibrium. Similar trends were reported for gum materials such as flaxseed gum [9], boat-fruited Sterculia seeds polysaccharide [10], and Yanang leaves gum extraction [6]. These results contrasted our results and probably reflected the nature of gum origin. In fact, while our gum source is more rigid in structure, then less affected by temperature, most reported sources of gums are either seeds or leaves.

It was also demonstrated that increase in water to seed ratio tended to increase the extraction yield, probably due to the available more liquid which increased the driving force of gum out of the material $[8,22]$. Conversely, some authors found a higher extraction yield at a low water to solid ratio [6]. The difference in the behavior of gum extraction yields towards the extraction time here again highlighted the effect of the nature of the gum source, but this needs to be investigated. In addition the difference in the gum structure may affect the extract yield; in particular solubility of charged gum is highly subjected to variation in $\mathrm{pH}$. The effect of $\mathrm{pH}$ on the yield reported for some gums origins revealed minor effect in agreement with our finding $[8,10]$ but contrasted with findings by others who reported higher extraction yield at alkaline [23] or acidic pH [24]. According to Karazhiyan et al. [22] the effect of alkaline pH may result from hydrolysis and dissolution of insoluble constituents, which in our case may not happen due to the woody nature, shrub, of our plant material.

The effects of extraction conditions on the viscosity of extracted gums of various natures have been reported. Koocheki et al. [8] found that, as the time and temperature of extraction increased, the viscosity of the extracted gum decreases in a parabolic manner as a result of irreversible change in their conformation [25]. In addition they reported increase in water to seed ratio also conducted to a gum with lower viscosity while $\mathrm{pH}$ has no significant effect, particularly at lower water to seed ratio. Karazhiyan et al. [22] also reported similar effect of water to seed ratio, temperature, and $\mathrm{pH}$ on viscosity.

3.5. Contours Plotting, Interaction Effect, and Optimization. Figure 3 presents the contours plot of the interaction effect of water to powder ratio and extraction time on the viscosity 
TABLE 3: Coefficients and analysis of variance of the effect of time, $\mathrm{pH}$, temperature, and powder to water ratio on the viscosity of Grewia gum extract.

\begin{tabular}{|c|c|c|c|c|c|}
\hline Source & Coefficient & Sum of square & Df & $F$ ratio & $P$ value \\
\hline Linear & 1.0657 & & & & \\
\hline \multicolumn{6}{|l|}{ Constant } \\
\hline Time (h) & -1.4624 & 0.0656 & 1 & 1.03 & 0.3266 \\
\hline $\mathrm{pH}$ & 0.394686 & 0.0180 & 1 & 0.28 & 0.6032 \\
\hline Temperature $\left({ }^{\circ} \mathrm{C}\right)$ & 0.0353305 & 0.0261 & 1 & 0.41 & 0.5318 \\
\hline Ratio & 0.0391614 & 0.6450 & 1 & 10.11 & $0.0062^{*}$ \\
\hline \multicolumn{6}{|l|}{ Quadratique } \\
\hline Time $\times$ time & 0.324119 & 0.2773 & 1 & 4.35 & 0.0546 \\
\hline $\mathrm{pH} \times \mathrm{pH}$ & -0.029087 & 0.2058 & 1 & 3.23 & 0.0926 \\
\hline Temperature $\times$ temperature & -0.000305 & 0.2001 & 1 & 3.14 & 0.0968 \\
\hline Ratio $\times$ ratio & 0.000326 & 0.4221 & 1 & 6.62 & $0.0212^{*}$ \\
\hline \multicolumn{6}{|l|}{ Interaction } \\
\hline Time $\times \mathrm{pH}$ & 0.00995434 & 0.0079 & 1 & 0.12 & 0.7305 \\
\hline Time $\times$ temperature & 0.00053787 & 0.0001 & 1 & 0.00 & 0.9698 \\
\hline $\mathrm{pH} \times$ temperature & -0.0000661 & 0.0003 & 1 & 0.00 & 0.9451 \\
\hline $\mathrm{pH} \times$ ratio & 0.00018535 & 0.0033 & 1 & 0.05 & 0.8222 \\
\hline Time $\times$ ratio & -0.00008227 & 0.0030 & 1 & 0.05 & 0.8321 \\
\hline Temperature $\times$ ratio & -0.00008382 & 0.0883 & 1 & 1.38 & 0.2578 \\
\hline Total error & 0.956746 & 0.9567 & 15 & & \\
\hline Total (corr.) & 4.57207 & 4.5721 & 29 & & \\
\hline
\end{tabular}

the corresponding coefficients are significant.

TABLE 4: Coefficients and analysis of variance of the effect of time, $\mathrm{pH}$, temperature, and powder to water ratio on the yield of Grewia gum extract.

\begin{tabular}{|c|c|c|c|c|c|}
\hline Source & Coefficient & Sum of square & Df & $F$ ratio & $P$ value \\
\hline Linear & 0.0601778 & & & & \\
\hline \multicolumn{6}{|l|}{ Constant } \\
\hline Time (h) & -0.452027 & 34.8446 & 1 & 0.10 & 0.7577 \\
\hline $\mathrm{pH}$ & 0.0502871 & 619.909 & 1 & 1.76 & 0.2048 \\
\hline Temperature $\left({ }^{\circ} \mathrm{C}\right)$ & 0.00641689 & 37.7153 & 1 & 0.11 & 0.7482 \\
\hline Ratio & 0.0131883 & 5999.3 & 1 & 17.00 & $0.0009^{*}$ \\
\hline \multicolumn{6}{|l|}{ Quadratique } \\
\hline Time $\times$ time & 0.0993363 & 20.2103 & 1 & 0.06 & 0.8141 \\
\hline $\mathrm{pH} \times \mathrm{pH}$ & -0.00276491 & 55.711 & 1 & 0.16 & 0.6967 \\
\hline Temperature $\times$ temperature & 0.000007664 & 10.5134 & 1 & 0.03 & 0.8653 \\
\hline Ratio $\times$ ratio & -0.000088 & 365.476 & 1 & 1.04 & 0.3249 \\
\hline \multicolumn{6}{|l|}{ Interaction } \\
\hline Time $\times \mathrm{pH}$ & 0.014648 & 185.664 & 1 & 0.53 & 0.4794 \\
\hline Time $\times$ temperature & -0.000926884 & 339.648 & 1 & 0.96 & 0.3421 \\
\hline $\mathrm{pH} \times$ temperature & -0.000718786 & 101.004 & 1 & 0.24 & 0.6005 \\
\hline $\mathrm{pH} \times$ ratio & -0.000289118 & 173.185 & 1 & 0.49 & 0.4943 \\
\hline Time $\times$ ratio & 0.000972389 & 75.5734 & 1 & 0.21 & 0.6501 \\
\hline Temperature $\times$ ratio & 0.0000096834 & 9.5103 & 1 & 0.03 & 0.8718 \\
\hline Total error & 0.607627 & 5292.5 & 15 & & \\
\hline Total (corr.) & 1.80606 & 14902.5 & 29 & & \\
\hline
\end{tabular}

"the corresponding coefficients are significant. 


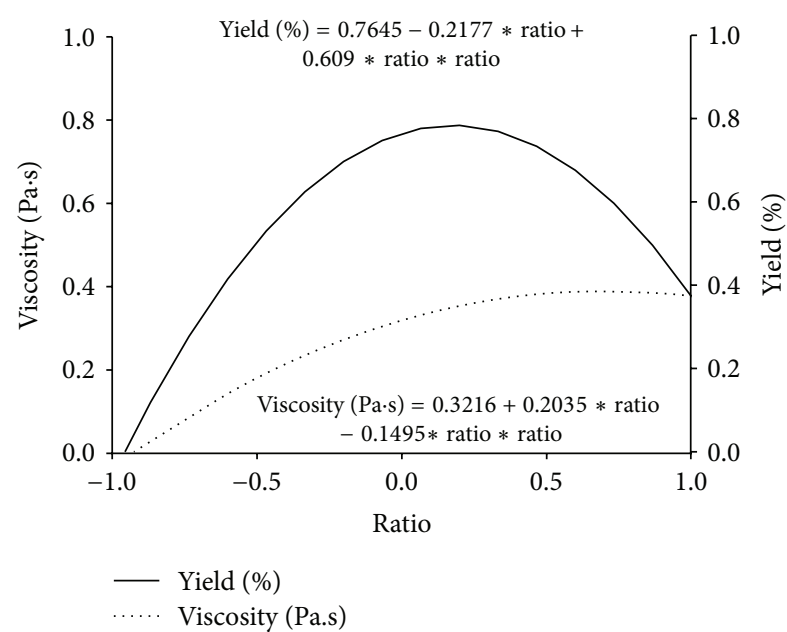

(a)

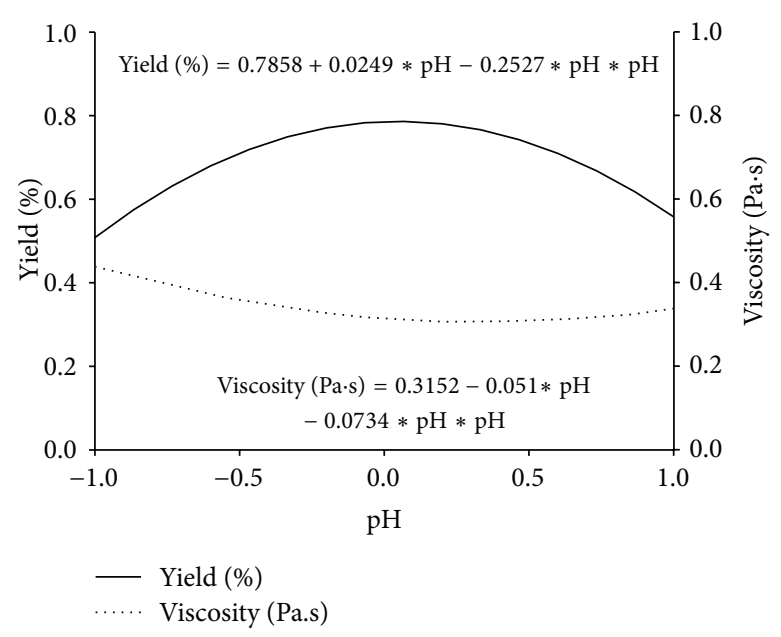

(c)

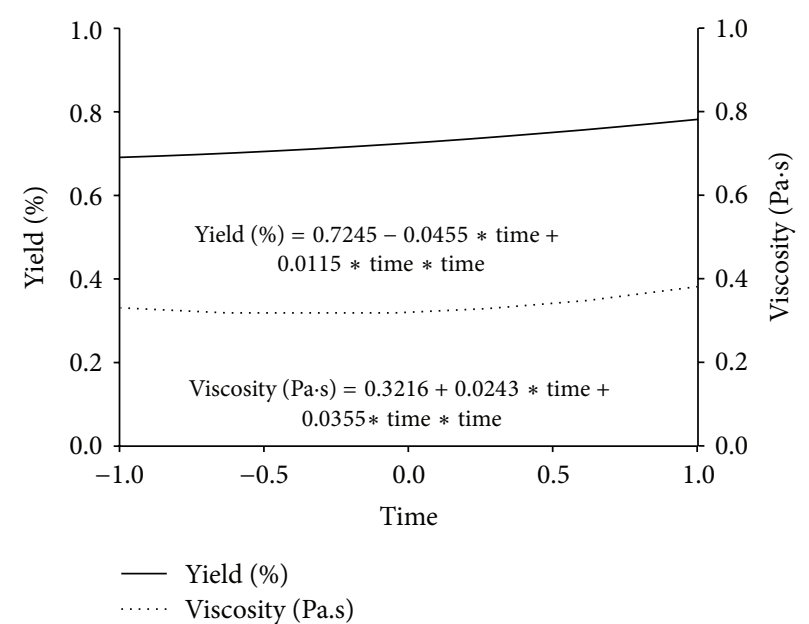

(b)

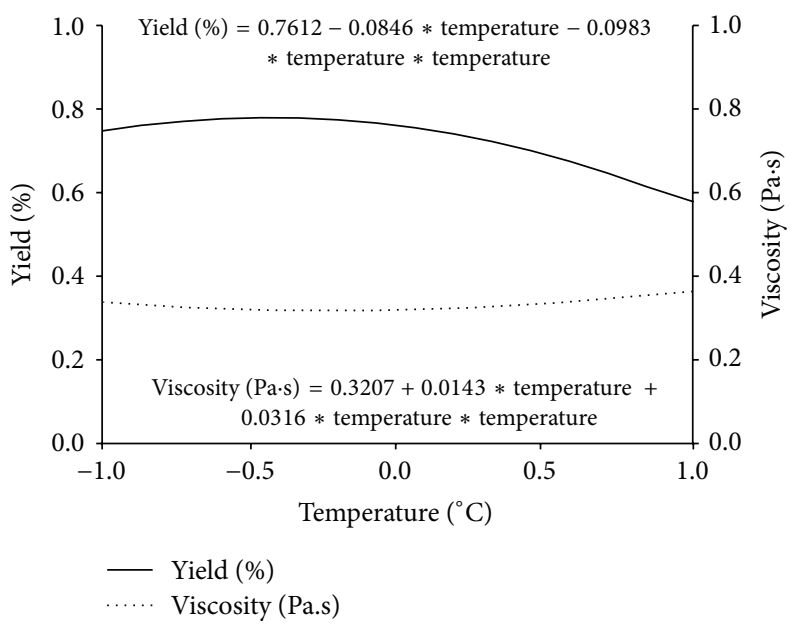

(d)

FIGURE 2: Quadratic representation of the effect of powder to water ratio (a), extraction time (b), extraction pH (c), and temperature (d) on the viscosity and yield of Grewia gum.

and yield of Grewia gum. Each contour plot was drawn when the other parameters were at the centre of the domain, that is, ratio $55: 1$, time $2 \mathrm{~h}$, temperature $55^{\circ} \mathrm{C}$, and $\mathrm{pH}$. As shown in Figure 3(a), the extraction time had no effect on the viscosity at water/powder ratio $10-40$ and $60-80$, while, between the ratio ranges 40 and 60 , an increase in the extraction time induced a decline in the viscosity from 1.2 Pa.s to less than $0.8 \mathrm{~Pa} \cdot \mathrm{s}$. On the other hand, irrespective of the extraction time, an increase in water/powder ratio from 10 to 55 was associated with an increase in viscosity after which a decline was observed. The highest viscosity was 1.2 Pa-s observed only at lower extraction time, a maximum which diminished as the extraction time increased. The interaction effects of the water/powder ratio and time on the yield showed no marked change with viscosity fluctuating between 0.1 and 0.4 .

The interaction effect of $\mathrm{pH}$ and water to powder ratio shown in Figure 4 revealed that $\mathrm{pH}$ exerted influence on the viscosity at water/powder ratio around $50: 1$. In these conditions an increase in $\mathrm{pH}$ from 4 to 7 led to an increase in viscosity (from 0.4 to $0.8 \mathrm{~Pa} \cdot \mathrm{s}$ ) above which a decrease was observed (Figure 4(a)). The effect on yield was also quite visible at water/powder ratio higher than 50:1 where an increase in $\mathrm{pH}$ led a nonsignificant decrease in yield from $0.5 \%$ to $0.2 \%$. The effect of temperature was similar to that of time with no significant effect at lower water powder ratio and some observed effect around ratio 40-60 (Figure 5). In this range of ratio an increase in temperature seemed to reduce viscosity and similar change was observed on yield.

The results obtained in this study revealed that viscosity and yield were most affected by the water : powder ratio, and to a lesser extent by time, $\mathrm{pH}$, and temperature of extraction. In order to identify the optimal conditions of Grewia gum extraction, the contours plot presented was used. In this respect the most suitable condition was considered optimal for Grewia gum extraction at the highest extraction yield and viscosity. Optimum was achieved graphically by identifying zones of maximum viscosity and gum yield as stripped in the contours plots in Figures 3, 4, and 5. The optimal extraction conditions zones for Grewia gum viscosity corresponded to the range temperature $25^{\circ} \mathrm{C}-85^{\circ} \mathrm{C}, \mathrm{pH} 6-8$, water to powder 


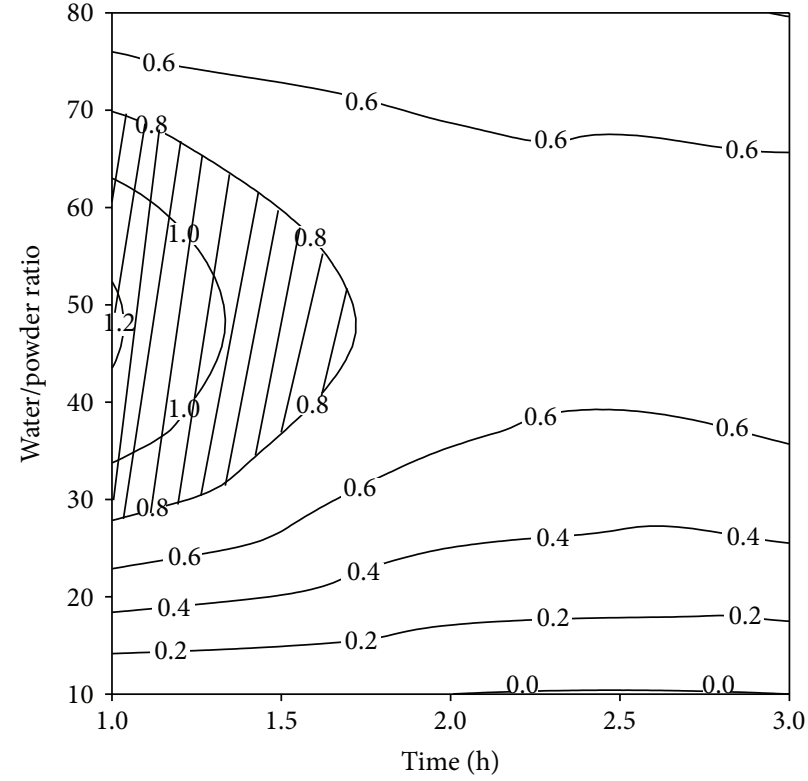

(a)

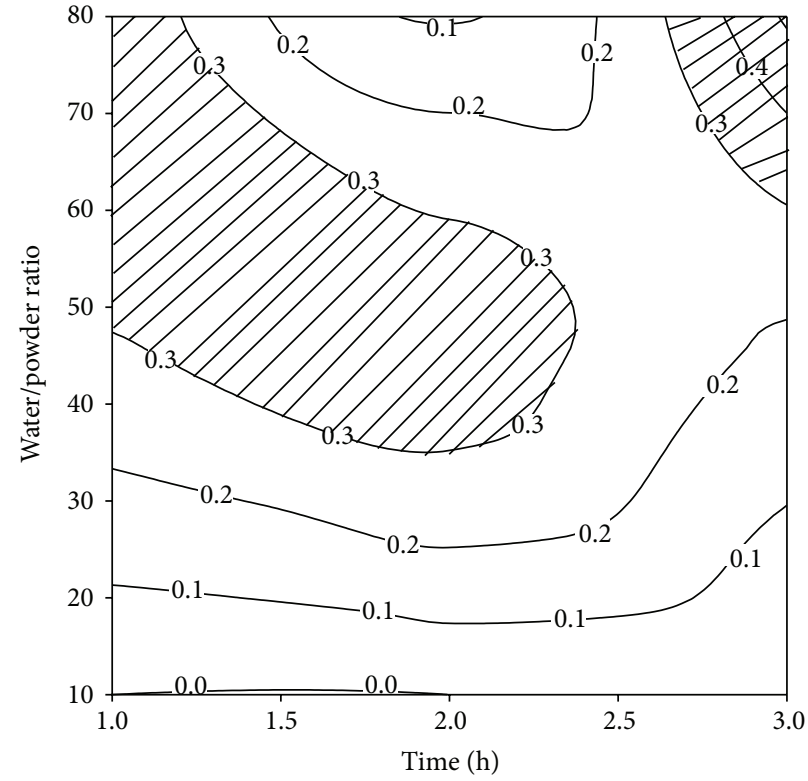

(b)

FIGURE 3: Interaction effects of water/powder ratio and extraction time on the viscosity Pa.s (a) and yield \% (b). pH and time extraction conditions were 7 and $2 \mathrm{~h}$, respectively.

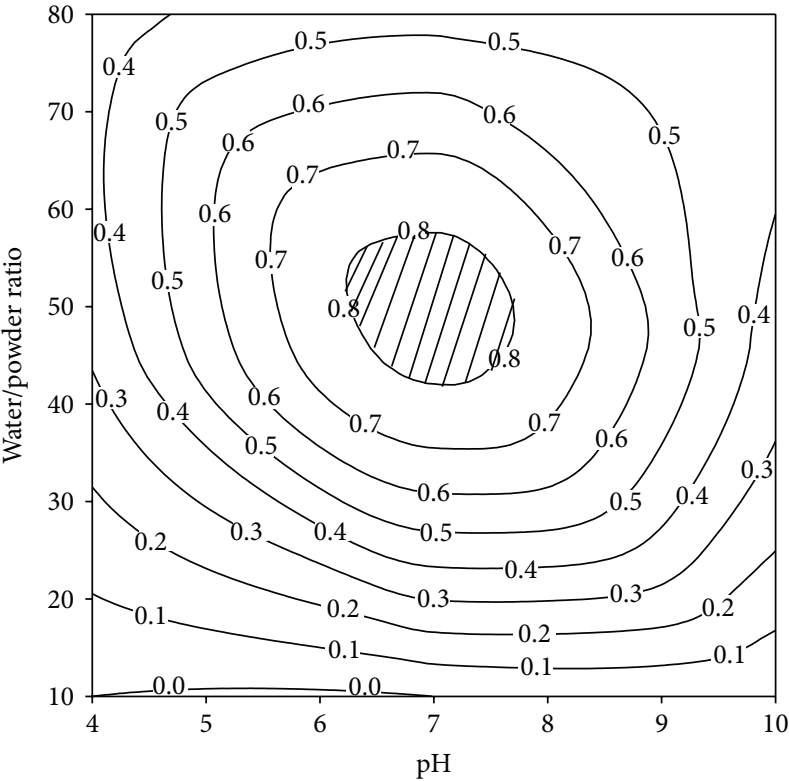

(a)

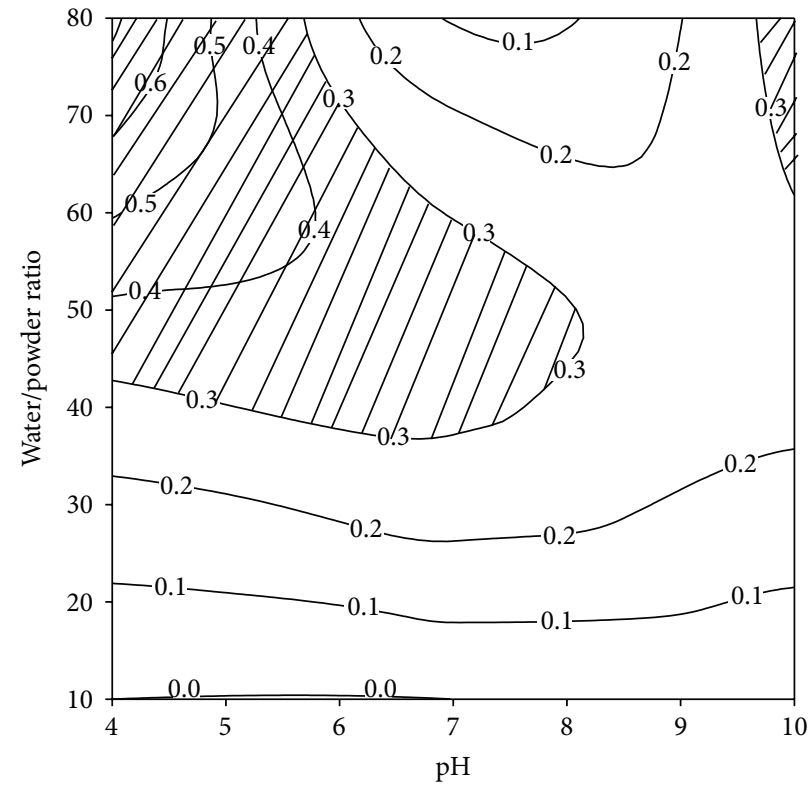

(b)

FIGURE 4: Interaction effects of water/powder ratio and $\mathrm{pH}$ on the viscosity Pa.s (a) and yield \% (b) of Grewia gum. Extraction time and temperature conditions were $2 \mathrm{~h}$ and $55^{\circ} \mathrm{C}$, respectively.

ratio $40: 1-60: 1$, and time of extraction $1 \mathrm{~h}-1.5 \mathrm{~h}$ while the corresponding zone for optimum yield was temperature 30$60^{\circ} \mathrm{C}, \mathrm{pH} 4-7$, water to powder ratio $50: 1-70: 1$, and time of extraction $1-2 \mathrm{~h}$, respectively. The optimum conditions of extraction were also computed for each yield and viscosity and the values given in Table 5 reflected the optimum determined graphically. Multiple graphical optimizations were performed by drawing the overlaid contour plot in order to establish the overall optimum area of aqueous extraction condition as shown in Figure 6. Since only water to powder ratio and time had significant effects on the viscosity and yield, only the graphs involving the water to shrub ratio and time as factors were used. Based on this, the extraction condition that maximized viscosity and yield of Grewia gum was water to powder ratio $50: 1-60: 1$ and extraction time 1$1.5 \mathrm{~h}$. 


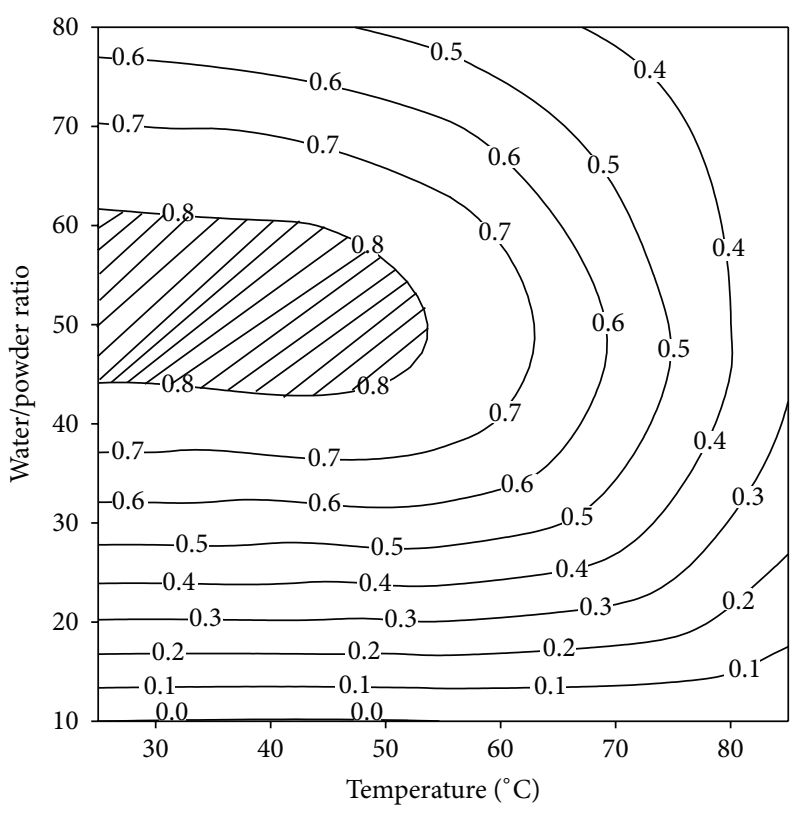

(a)

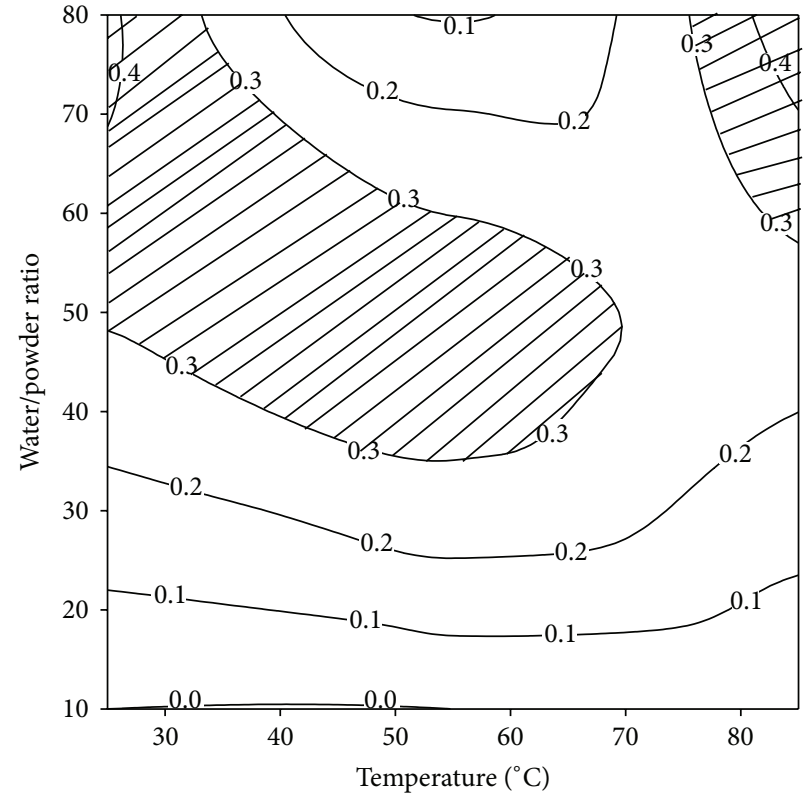

(b)

FIGURE 5: Interaction effects of water/powder ratio and temperature on the viscosity Pa·s (a) and yield \% (b) of Grewia gum. Extraction time and $\mathrm{pH}$ conditions were $2 \mathrm{~h}$ and 7 , respectively.

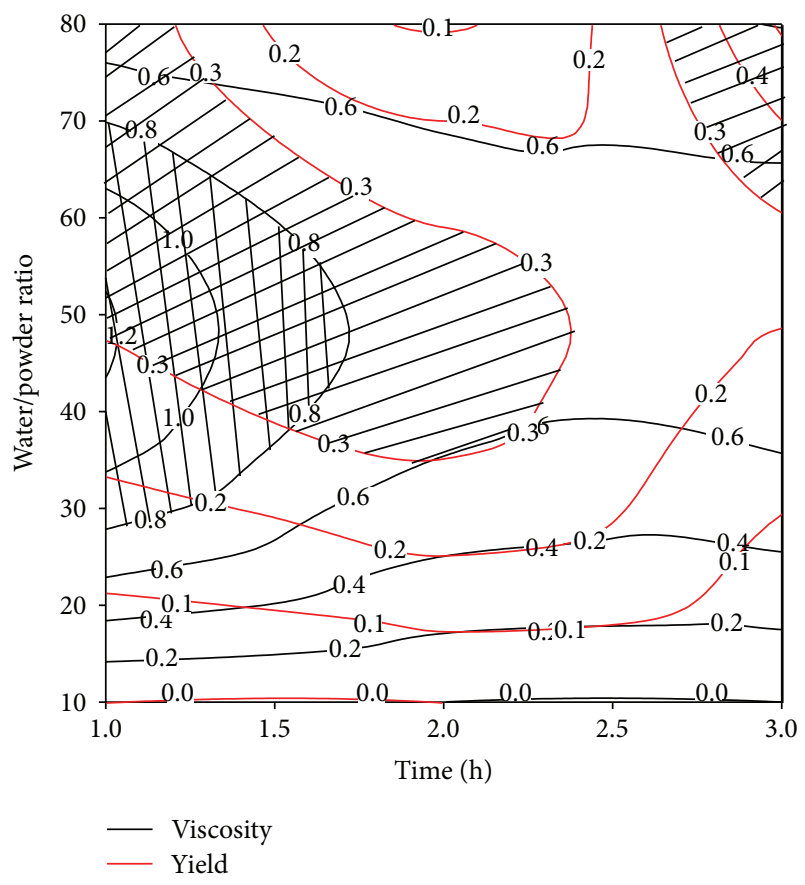

FIGURE 6: Overlaid plotting for multiple optimization of aqueous extraction of Grewia shrub gum.

As shown in Table 5 the numerical optimum corresponded to temperature $73^{\circ} \mathrm{C}$, time $1 \mathrm{~h}, \mathrm{pH} 7.0$, and water to powder ratio $55: 1$. In these conditions, the gum was extracted with a yield of $0.32 \mathrm{~g} / 100 \mathrm{~g} \mathrm{DM}$ and the gum solution possessed a viscosity of $0.98 \mathrm{~Pa} \cdot \mathrm{s}$, values which were close to desired values of $0.4 \mathrm{~g} / 100 \mathrm{~g} \mathrm{DM}$ and $1.2 \mathrm{~Pa} \cdot \mathrm{s}$, respectively.
TABLE 5: Computed predicted optimum conditions of extraction of Grewia mollis gum.

\begin{tabular}{lcc}
\hline Factor & Optimum viscosity & Optimum yield \\
\hline Times & $\mathbf{1 . 0}$ & 3 \\
$\mathrm{pH}$ & $\mathbf{7 . 1}$ & 4 \\
Temperature & 50.3 & $\mathbf{7 3 . 2}$ \\
Water : shrub ratio & $\mathbf{5 5 . 4 : 1}$ & $80: 1$ \\
\hline
\end{tabular}

Bold values were overlaid selected optimum conditions.

The viscosity of $2.5 \%$ gum extracted in these conditions falls within the range of values generally reported for other plants gum: $581.4 \mathrm{mPa} \cdot \mathrm{s}$ for Ocimum basilicum seed gum [20] and $518.9 \mathrm{mPa} \cdot \mathrm{s}$ for Lepidium perfoliatum [8]. In addition, the yield, however, was lower compared to most seeds gums reported in previous studies such as Yanang gum 4.54\% [6], Flaxseed gum 7.9\% [9], Opuntia mucilage 19.4\% [26], and Mesquite seed gum $24.9 \%$ [25], but much higher compared to $1.2 \%$ reported for Durio zibethinus seed gum [27].

Based on its lower extraction yield compared to the most commercial gum, the use of Grewia gum as a novel food hydrocolloid is questionable. In addition the part of the plant used, the shrub, can also lead to the destruction of the plants if harvesting is not appropriately conducted.

\section{Conclusion}

Results showed that extraction conditions significantly influenced the extraction yield and apparent viscosity. The most important variable is the water to powder ratio, whereas the effects of extraction temperature, time, and $\mathrm{pH}$ are less important. Increasing water to powder ratio resulted in an 
increase yield and viscosity up to maximum at ratio $55: 1$ from which a decrease is observed. Based on numerical optimization and significant factors, the optimal extraction condition of Grewia gums is temperature $73^{\circ} \mathrm{C}, \mathrm{pH} 7$, time $1(\mathrm{~h})$, and water to powder ratio 55:1. This investigation confirms the use of Grewia gum as gelling agent and the carbohydrate nature of its gum. Studies of its gelling power need to be studied. However the yield is lower compared to commercial gum and this hypothesizes its eventual use as a new source of hydrocolloid for industry.

\section{Conflict of Interests}

The authors declare that there is no conflict of interests regarding the publication of this paper.

\section{Acknowledgment}

The authors would like to thank the Cooperation pour la Recherche Universitaire (CORUS-IRD ref 6052, FRANCE) for financial support.

\section{References}

[1] J. Muazu, H. Musa, and K. Y. Musa, "Compression, mechanical and release properties of paracetamol tablet containing acid treated Grewia gum," Journal of Pharmaceutical Science and Technology, vol. 1, no. 2, pp. 74-79, 2009.

[2] M. Emeje, C. Isimi, and O. Kunle, "Effect of Grewia gum on the mechanical properties of paracetamol tablet formulations," African Journal of Pharmacy and Pharmacology, vol. 2, pp. 1-6, 2008.

[3] E. I. Nep and B. R. Conway, "Physicochemical characterization of grewia polysaccharide gum: effect of drying method," Carbohydrate Polymers, vol. 84, no. 1, pp. 446-453, 2011.

[4] F. C. Onwuliri, J. D. Mawak, D. L. Wonang, and E. A. Onwuliri, "Phytochemical, toxicological and Histopathological studies of some medicinal plants in Nigeria," International Journal of Natural and Applied Sciences, vol. 2, no. 3, pp. 225-229, 2006.

[5] W. Obidah, J. L. Godwin, J. Z. Fate, and M. A. Madusolumuo, "Toxic effects of Grewia mollis stem bark in experimental rats," Journal of American Science, vol. 6, no. 12, pp. 1544-1548, 2010.

[6] J. Singthong, S. Ningsanond, and S. W. Cui, "Extraction and physicochemical characterisation of polysaccharide gum from Yanang (Tiliacora triandra) leaves," Food Chemistry, vol. 114, no. 4, pp. 1301-1307, 2009.

[7] D. Seisum, "Market overview," in Gums and Stabilizers for the Food Industry, P. A. Williams and G. O. Phillips, Eds., vol. 11, pp. 4-9, The Royal Society of Chemistry, London, UK, 2002.

[8] A. Koocheki, A. R. Taherian, S. M. A. Razavi, and A. Bostan, "Response surface methodology for optimization of extraction yield, viscosity, hue and emulsion stability of mucilage extracted from Lepidium perfoliatum seeds," Food Hydrocolloids, vol. 23, no. 8, pp. 2369-2379, 2009.

[9] W. Cui, G. Mazza, B. D. Oomah, and C. G. Biliaderis, "Optimization of an aqueous extraction process for flaxseed gum by response surface methodology," LWT-Food Science and Technology, vol. 27, no. 4, pp. 363-369, 1994.

[10] Y. Wu, S. W. Cui, J. Tang, and X. Gu, “Optimization of extraction process of crude polysaccharides from boat-fruited sterculia seeds by response surface methodology," Food Chemistry, vol. 105, no. 4, pp. 1599-1605, 2007.

[11] A. Koocheki, S. A. Mortazavi, F. Shahidi, S. M. A. Razavi, R. Kadkhodaee, and J. M. Milani, "Optimization of mucilage extraction from Qodume Shirazi seed (Alyssum homolocarpum) using response surface methodology," Journal of Food Process Engineering, vol. 33, no. 5, pp. 861-882, 2010.

[12] AOAC, Methods of Association of Official Chemist. Official Methods of Analysis, Association of Official Analytical Chemists, Arlington, Va, USA, 15th edition, 2005.

[13] N. Y. Njintang, C. M. F. Mbofung, and K. W. Waldron, "In vitro protein digestibility and physicochemical properties of dry red bean (Phaseolus vulgaris) flour: effect of processing and incorporation of soybean and cowpea flour," Journal of Agricultural and Food Chemistry, vol. 49, no. 5, pp. 2465-2471, 2001.

[14] H. Karazhiyan, Extraction optimization and physical properties of cress seed hydrocolloid using response surface methodology [Ph.D. thesis], Ferdowsi University of Mashhad, Mashhad, Iran, 2008.

[15] R. M. Nguimbou, T. Boudjeko, Y. N. Njintang, M. Himeda, J. Scher, and C. M. F. Mbofung, "Mucilage chemical profile and antioxidant properties of giant swamp taro tubers," Journal of Food Science and Technology, 2013.

[16] P. Albersheim, D. J. Nevins, P. D. English, and A. Karr, "A method for the analysis of sugars in plant cell-wall polysaccharides by gas-liquid chromatography," Carbohydrate Research, vol. 5, no. 3, pp. 340-345, 1967.

[17] G. S. Pallardy, The Physiology of Woody Plants, Burlington, Mass, USA, 3rd edition, 2008.

[18] E. I. Nep, P. O. Odumosu, N. C. Ngwuluka, P. O. Olorunfemi, and N. A. Ochekpe, "Pharmaceutical properties and applications of a natural polymer from Grewia mollis," Journal of Polymers, Article ID 938726, 8 pages, 2013.

[19] Q. Wang and S. W. Cui, "Understanding the physical properties of food polysaccharides," in Food Carbohydrates: Chemistry, Physical Properties, and Applications, S. W. Cui, Ed., pp. 162-214, Taylor and Francis, Boca Raton, Fla, USA, 2005.

[20] S. M. A. Razavi, S. A. Mortazavi, L. Matia-Merino, S. H. Hosseini-Parvar, A. Motamedzadegan, and E. Khanipour, "Optimisation study of gum extraction from Basil seeds (Ocimum basilicum L.)," International Journal of Food Science and Technology, vol. 44, no. 9, pp. 1755-1762, 2009.

[21] B. T. Amid and H. Mirhosseini, "Influence of different purification and drying methods on rheological properties and viscoelastic behaviour of durian seed gum," Carbohydrate Polymers, vol. 90, pp. 452-461, 2012.

[22] H. Karazhiyan, S. M. A. Razavi, and G. O. Phillips, "Extraction optimization of a hydrocolloid extract from cress seed (Lepidium sativum) using response surface methodology," Food Hydrocolloids, vol. 25, no. 5, pp. 915-920, 2011.

[23] P. Somboonpanyakul, Q. Wang, W. Cui, S. Barbut, and P. Jantawat, "Malva nut gum. (Part I): extraction and physicochemical characterization," Carbohydrate Polymers, vol. 64, no. 2, pp. 247253, 2006.

[24] H. Furuta, T. Takahashi, J. Tobe, R. Kiwata, and H. Maeda, "Extraction of water-soluble soybean polysaccharides under acidic conditions," Bioscience, Biotechnology and Biochemistry, vol. 62, no. 12, pp. 2300-2305, 1998.

[25] A. M. Estévez, C. Sáenz, M. L. Hurtado, B. Escobar, S. Espinoza, and C. Suárez, "Extraction methods and some physical properties of mesquite (Prosopis chilensis (Mol) Stuntz) seed gum," 
Journal of the Science of Food and Agriculture, vol. 84, no. 12, pp. 1487-1492, 2004.

[26] E. Sepúlveda, C. Sáenz, E. Aliaga, and C. Aceituno, "Extraction and characterization of mucilage in Opuntia spp," Journal of Arid Environments, vol. 68, no. 4, pp. 534-545, 2007.

[27] A. M. Amin, A. S. Ahmad, Y. Y. Yin, N. Yahya, and N. Ibrahim, "Extraction, purification and characterization of durian (Durio zibethinus) seed gum," Food Hydrocolloids, vol. 21, no. 2, pp. 273279, 2007. 

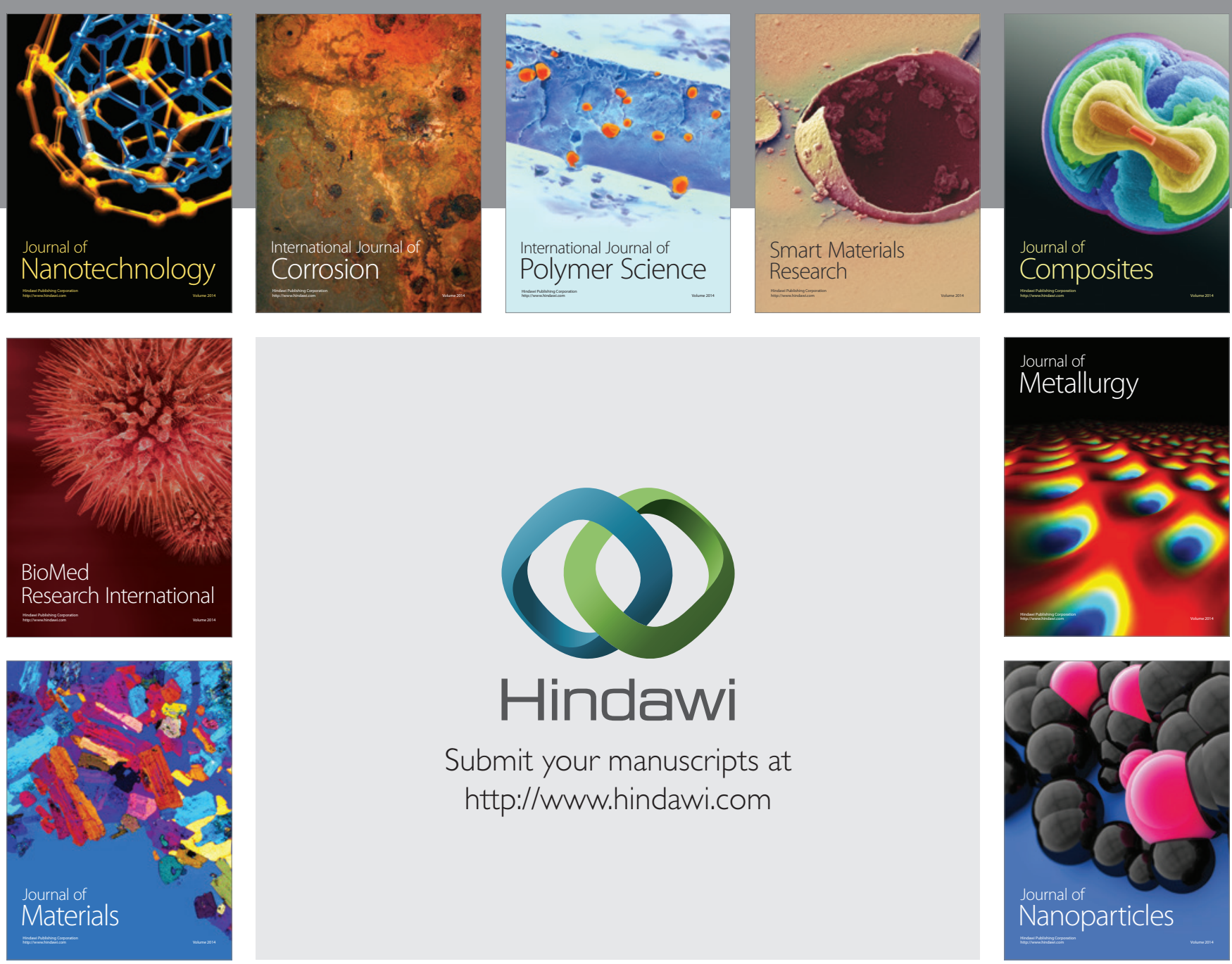

Submit your manuscripts at http://www.hindawi.com
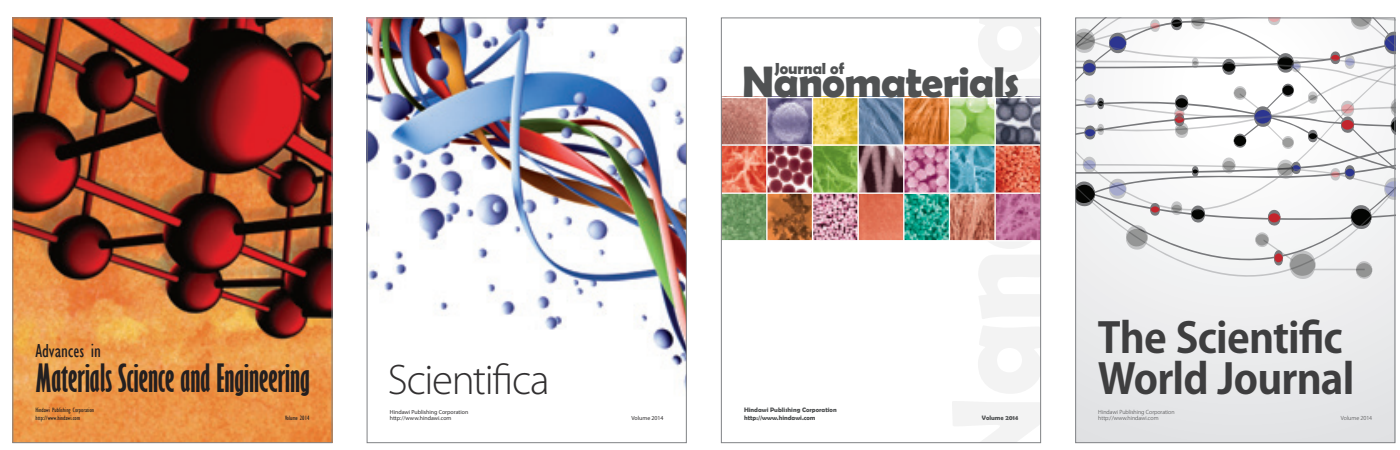

\section{The Scientific World Journal}
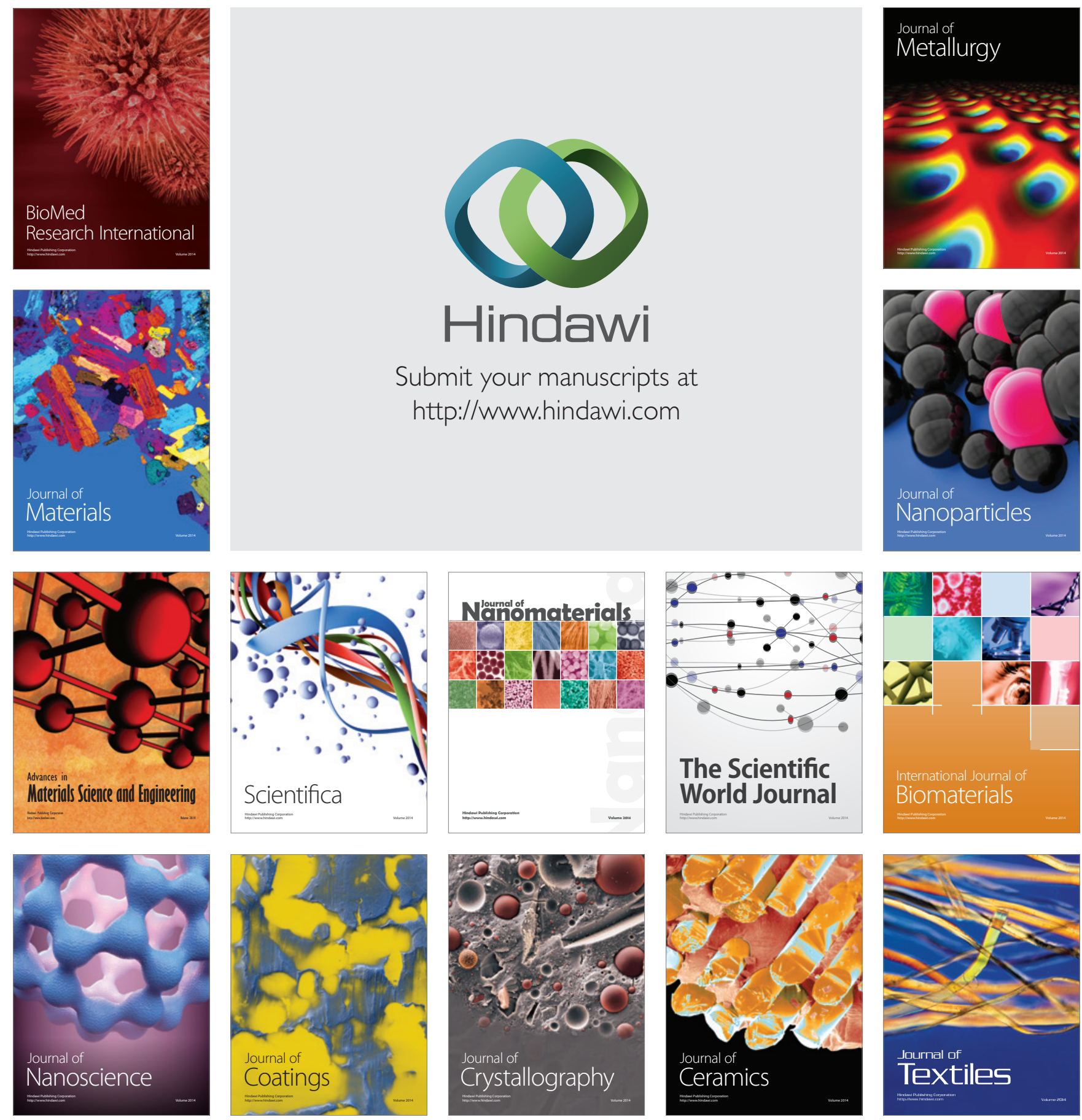